\title{
MISTREATMENT OF CHILDREN IN THE ARMED CONFLICTS
}

\author{
Toni Petreski, PhD \\ Ministry of defense of the Republic of Macedonia \\ E-mail: tonipetreski68@yahoo.com
}

\begin{abstract}
Through the history, in many countries with different cultures, the children have been abused and have been forced to engage in a conflict because of the poverty, or their parents have sold them in ability to feed them, but most of them are either kidnapped or manipulated in order to join the terrorists. In the previous century, a great number of international conventions became effective in order to restrict the children's involvement into the armed conflicts. The most important convention is the Geneva Convention, a convention adopted on August 12 1949. It clearly states that both sides in conflict must take all measures of not recruiting children who have not turned 15 years of age and must not be involved directly in the conflict. In this paper, we will analyze and see if these conventions are respected and how are implemented.
\end{abstract}

Key words: children-warriors, armed conflicts, poverty, rehabilitation.

\section{Introduction}

The word, war" usually refers to an armed conflict between two countries. The term, armed conflict "is more general and it refers to inner conflict such as the civil war. In this written paper, both of the terms are used. It is clear that in the wars and armed conflicts, great horrors occur, a lot of human casualties and great harm, as well. These are military 


\section{Security}

terms for the civil casualties, or for destroying non-military objects during military actions. Consequences occurred with random circumstances and not as prime objective.

However, it seems the greatest collateral victims are children. During the history of wars and armed conflicts, millions of children have been murdered, seriously handicapped or injured, displaced, sexually abused or they are being used as children - warriors (children - soldiers). Not to mention that, many of them are left orphans or education is being forbidden. (..."the images are burned into our minds: a young boy dressed in tee shirt, shorts, flip-flops, holding an AK-47, a cap pulled down over too-old eyes; a child with sticks of dynamite strapped to his chest; a tough-talking twelve-year old in camouflage. The images disturb us because they confound two fundamental and unquestioned assumptions of modern society: war is evil and should be ended; children are innocent and should be protected. Therefore, our emotional logic tells us, something is clearly and profoundly wrong when children are soldiers. Throughout the world, humanitarian organizations are using the power of these images to drive forward the argument that children should not bear arms and that the adults who recruit them should be held accountable and should be prosecuted for war crimes. The humanitarian case, which in one facet of the general effort to abolish war, rests on three basic assumptions: that modern warfare is especially aberrant and cruel; that the worldwide glut of light- weight weapons makes it easier than in the past for children to bear arms; and that venerable children become soldiers because they are manipulated by unscrupulous adults. In making this case against child soldiers, humanitarian organizations paint the picture of a new phenomenon that has become a crisis of epidemic proportions"). ${ }^{24}$

\section{Historic review}

Throughout history, in many cultures, children were intensively abused as children - warriors (soldiers) in war campaigns. Proofs of that can be found in an ancient Greek mythology, philosophy and literature, later in old Roman legions, young boys at the age of sixteen were recruited.

\footnotetext{
${ }^{24}$ David M. Rosen, "Armies of the young: Child Soldiers in War and Terrorism"- Rutgers University Press: New Brunswick, New Jersey, and London 1989, p. 1
} 


\section{Secuurity}

- In Central Europe, even in 1212, thousands of children at age between 12 and 17 were used for war purposes.

- Napoleon Bonaparte, in 1834, used many teenagers in his army. ${ }^{25}$

- Children were used on the battle ships of the British Royal Navy, during the ruling of the Russian tsar Nikolai the first in 1827, and in the Civil War in America. The Civil War in the United States was a war of boy soldiers. Throughout the Civil War, youngsters followed brothers, fathers, and teachers into war. Some lied about their age; others looked older than their age. They were sometimes recruited at school, and many were brought to the recruiting by their parents. They often had support roles but quickly graduated into combat roles. When necessary, they used weapons that were cut down and adapted for use by young people. Numerous examples abound. ${ }^{26}$

- During the First World I, young boys continued to enlist, despite official age restrictions on recruitment. Private James Martin, the youngest Australian to die in World War I, enlisted in Melbourne in 1915 at age fourteen and died a few months later near Gallipoli. Anthony Hill memorializes his story in the book "Soldier boy". Albert Cohen of Memphis, Tennessee, is reputed to the youngest U.S. soldier to see combat in World War I. He enlisted at age thirteen and died at age fifteen. However, youngest and most famous soldier was Momcilo Gavric, who joined the sixth artillery division with only 8 years of age on his behalf. Right after, the Austro - Hungarian army in August 1914, murdered his parents and relatives. Alongside Momcilo, many other children took part in the bloodiest battles of the war. ${ }^{27}$

- In the World War II, the youngest member of the USA army was Calvin Graham. He lied about his age, but he was discovered when he was wounded. ${ }^{28}$

- Adolf Hitler, even before the war, through psychological training, indoctrinated young people with Nazi ideology called "Hitler's youth ". Later on, from that organization, he (Adolf) recruited officers for the national army. At the beginning of 1945, many children were taken from schools and sent to the fronts to fight. It is also known that in the first

\footnotetext{
${ }^{25}$ Michael Leggiere, "The fall of Napoleon: the allied Invasion of France 1813-1814", pg. 99-100

${ }^{26}$ David M. Rosen, "Armies of the young: Child Soldiers in War and Terrorism"- Rutgers University Press: New Brunswick, New Jersey, and London 1989, p. 5

27 "Momcilo Gavric-the youngest soldier in the World War-One"- Vecernje novelty, 13 avgust 2013

28 "Interesting Facts About World War II", Armed forces History Museum, Retrieved on 10 April 2015
} 


\section{Security}

Battalion, around $65 \%$ of the soldiers were at the age of 18 . In addition, in the Panzer Tank division, there were over 10000 young boys. ${ }^{29}$

- Japanese armed forces trained young teenagers to fight the enemy. Some Japanese children were trained to be kamikazes - suicide pilot bombers. ${ }^{30}$

- Great number of children - warriors was recruited in the red army of the Soviet Union. ${ }^{31}$ In Great Britain, children under age of 17 were involved in the preparations against the German invasion, as, the last line of defense "in $1940 .^{32}$

- In the partisan history and in the literature of the Yugoslavian people, there are examples where, children were involved in combat against the fascists. One of the most famous examples is Bosko Buha, his unit known as; Partisan artillery "was composed of a lot of children and young people. Bosko buha was also known, for destroying the enemy bunkers with hand grenades, he died at age of 17 . After the war, he was proclaimed a National Hero!

\section{The International Law}

In order to protect the children from all these sufferings, right after the First World War, the League of Nations, adopted Geneva Declaration on the Rights of Children in 1924. According to this document, children around the world must be protected from any form of exploitation. The next Geneva Convention is declared in 1949 on 12 of August. It clearly states: both conflicted sides must take every measures not to recruit children less than 15 years of age. They (children) must not, directly, take part in the conflict.

From the seventies of the previous century until now, great number of international conventions came into power, these are additional declarations and protocols, trying to limit and reduce the involvement of children in armed - military conflicts.

- In the Article 77 of the additional Protocol (of the Geneva Convention) from 1977, says that the sides involved in the conflict must take every possible measures, to prevent

\footnotetext{
${ }^{29}$ Hitler Youth "The History Place, Retried on 14 April 2015

${ }^{30}$ Eigen Louis D. "Child soldiers are unfortunately nothing new', Scriptamus.worldpress.com, Retied on 26 April 2015

${ }^{31}$ Simkin John, "The red Army", Imperial war Museum, Retried on 22 April 2015

32 IVM Sraff, "The real Dad" Army", Imperial war Museum, Retrieved on 22 April 2015
} 


\section{Security}

children under 15 years of age to take directly part in the hostilities, and are especially bound, to restrain themselves from recruitment of children in their armed forces.

- In the Convention on the Rights of Children, from 1989, a definition is given, in which: A Child is every person, younger than 18 years, unless if in some countries adulthood is being gained earlier, but in the article 38, the lower limit for recruitment of children for hostile activities, is 15 years.

- Roman statute of the International Crime Court (ICC) that was declared in 1998, but came to power in 2002, ${ }^{33}$ says that: the recruitment of children younger than 15 years, and their active involvement in hostile activities, defines it as Crime of War. ${ }^{34}$

- On 12 of February 2002, the Optional Protocol came to power, as continuation of the Convention on the Rights of Children, which refers to involvement of children in armed conflicts. ${ }^{35}$ With this Protocol, all countries around the World are obligated to prevent young people under 18 years of age, to be part of the armed forces of a certain country taking directly part in hostile activities. Furthermore, armed groups that are not part of the official armed forces of a certain country, must not under any circumstances, recruit or use in hostile activities, persons younger than 18 years. Until now, this protocol has been signed by 150 countries, and ever since, every year on 12 of February, the Red Hand Day, has been celebrated. In other words, on that day, in many countries in the World, we are being reminded, with red prints on our palm, about the children who were forced to wear weapons.

- United Nations Security Council in 1999 adopted the Resolution 1261. By this Resolution, the Council can call sessions, discuss and produce decisions about the abuse of the children in the World, under the title "The Children in Armed Conflicts ". ${ }^{36}$

- In 2005, the council adopts the 1612 Resolution, where the Council demands, the Action Plan adopted by the Secretary General of the United Nations for establishing monitoring, reporting and mechanism of harmonization to be implemented without further

\footnotetext{
${ }^{33}$ Rome statute of the International Criminal Court Article 8- War crimes

${ }^{34}$ According the Statute of the International Criminal Court, the Congo War dictator Thomas Lubanga has been sentenced on 14 years of prison for recruitment and use of children-soldiers in his rebel army in 2002-2003- "Utrinski vesnik", 10.07.2012

35 UNICEF: Optional Protocol to the Convention on the Rights of Child. Unicef, 30 November 2005

${ }^{36}$ United Nation Security Council Verbatim report 5936. S/PV/5936
} 


\section{Security}

ado. In the same Resolution, says that: every child murdered, forced to kill or is an eye witness of the brutality of the war in conflict, is considered, a victim. ${ }^{37}$

- Republic of Macedonia, too, prevents the use of children in armed conflicts, with a Law. Therefore, the Law itself, within article 12, paragraph five, states: In Macedonia is forbidden, involvement of the children n-armed conflicts and their recruitment in units performing military activities". ${ }^{38}$

\section{The situation today}

Despite all adopted conventions, declarations and protocols with which the use of children in armed conflicts is forbidden, the situation on terrain, not only, has not improved, but we can easily say that, today, the situation is even worse. The director of UNICEF, Anthony Lake, stated: Never in recent history, have so many children been exposed to such brutality". ${ }^{39}$ Here are several examples from some countries:

-According to federal ministry for combat issues, in Bosnia and Herzegovina, around 2000 children were involved in the battles during the war from 1992 until 1995. However, the exact number of children involved in the conflict has never been found out. In 2001, United Nations sources state that, that number is somewhere around 3000 and $4000.4^{40}$

-During the crisis in Kosovo, which lasted from 1998 to 1999, Para-military and armed groups were reported to have recruited children within their ranks. In October 2000, approximately 10 per cent of the 16,024 registered soldiers with the Kosovo Liberation Army (KLA) were reportedly children, the majority of whom were between the ages of 16 and 17. Journalistic sources offer anecdotal evidence those children as young as 14 were associated with the KLA.

\footnotetext{
${ }^{37}$ There are divided opinions in the world, if the children soldiers should be prosecuted, or not. Some think that they should be prosecuted, and some think should not be and third party thinks, they should be, but their age should come strongly under a consideration.

${ }^{38}$ Law on Child Protection- official Journal of Republic of Macedonia, num.23, 14.02.2013

39 UNICEF: "In 2014 over 15 million of children were victims of violence in the World", "Utrinski vesnik", 08.12 .2014

${ }^{40}$ Children warriors from Bosnia, abounded by foreign countries, Balkan Insight, 21 may 2014
} 


\section{Security}

-Children under the age of 18 , and as young as 12 , have reportedly been recruited into opposition separatist forces in the Chechen Republic and other parts of the north Caucasus. The Coalition to Stop the Use of Child Soldiers (2004) has indicated that Chechen Boys have participated in a number of armed political groups including the main Chechen armed opposition, Islamist groups and village-based defense units. Boys are also believed to be involved in criminal gangs of under-18s, which were often attached to local fighters seeking to profit from the war economy. ${ }^{41}$

- Palestine is one of the leading countries in the Word that actively uses children warriors in all forms. The children have mostly been used as couriers for organizations such as Fatah, Hamas and Islamic jihad, but unofficially the children have been also abused like suicide bombers, known with the Palestinian people as "Martyrs of Palestine ".

- In the past 15 years in Uganda, have been recruited around 10000 children warriors. After the psychological handling, the children executed the greatest crimes without asking. UNICEF in its reports states that Ugandan army has interests in 8 years old of age children but there have been cases where the army kidnapped children at 5 years of age.

- In Congo and Sudan, in order to, break" the children, psychology-wise, while practice; children were forced to kill their closest friend.

- The Civil War in Sierra Leone is among the most brutal conflicts in the last years in the world. Its horrible specific is, forcing the children to execute war - crimes in the name of the, Revolutionary interests ". For women and girls in the RUF, the provision of sexual services to the men and boys in the group was, perversely, included as part of their expected "duties". Indeed, all but two girls interviewed reported being subjected to repeated sexual violence, and gang and individual rape were common. The rampant nature of sexual violence accords with other research conducted on girl soldiers in Africa. ${ }^{42}$ It is claimed

\footnotetext{
${ }^{41}$ Myriam Denov, "Child Soldiers- Sierra Leones Revolutionary United Front"- Cambridge University Press- 2010, p.28-29

${ }^{42}$ One of the girls remembered: "We were used as sex slaves. Whenever they wanted to have sexual intercourse with as, they took as away forcefully and brought us back when they finished with us. Sometimes, other officers took us up as soon as we were being finished with and subsequent ones were particularly painful..... don't even know who might have been the father of my child. Same, p.109
} 
that, around 6000 children, boys and girls kidnapped during the Civil War, were forced to take a part in the rebel formations, like soldiers. ${ }^{43}$

- In Liberia, during the ruling of Charles Taylor from 1989 to 2003, thousands of children, at age of 10 to 12, were kidnapped from the conquered villages. These children were trained to handle a firearm and machetes, after that, they were drugged and sent in a combat. These children have committed the most terrible massacres in the most recent World history.

- Terrorist groups, in Pakistan, load the children with bombs and sent them into attacks. This dreadful reality was discovered by the Pakistani police in 2013 . The police arrested 11 children, at the age of 8 to 15 used as terrorists. Police officials stated that all children came from poor families. The terrorist groups paid the families 20 to 25 dollars for a single child. ${ }^{44}$

- In March 2015, the extremist group Boko Haram kidnapped more than 400 young women and children in Nigeria. More than 50 of them killed on sight and the other girls used for sexual services for the, esteemed "warriors of Boko Haram. ${ }^{45}$

- The Islamic group, Islamic State "recruits children for the so called, Cubs of the Caliphate 46 ". Children were recruited in the homes, schools and mosques in parts of Syria and Iraq, where local population was killed and brutally punished. Children - warriors have been used for protecting the checkpoints, gathering intelligence from the areas that are not controlled by, Islamic State ", even for execution of prisoners or for suicide bomb attacks. At the beginning of March 2105, Islamic State "released an internet - video where a Palestinian hostage has been killed by a child, with a gun.

\section{Consequences}

Children, who took part in armed conflicts, suffer from post-traumatic stress disorder. They have depression, nightmares, lack of concentration, no trust in other people, and sometimes they find it difficult to control their actions and emotions. They often

\footnotetext{
43 "Soldiers smaller than a rifle: abducted childhood", Vreme num. 563, 18.10.2001

44 "Children like a cannon fodder on the Fronts", "Dnevnik", 22.03.2013

45 "Boko Haram reportedly kidnapped more than 400 woman and children in Damask"Reuters,03/24/2015

46 "Islamic state has Recruited at least 400 Children in Syria since January, Reuters, 3/25/2015
} 


\section{Security}

become drug addicts. A lot of them commit suicide. The others can 't run a normal life. They, very often, from victims become offenders and abuse their own children. ${ }^{47}$

"And, when they realize that, they are not in a position to live a normal life, many of them head back committing war activities. It is especially hard for the girls who, as, children - soldiers, were raped and got pregnant. ${ }^{48}$ In addition, when they go back to the village, simply no one wants them. They are condemned to life in solitude and poverty - says German, trauma doctor and therapist, Elisabeth Kaiser. ${ }^{49}$

\section{Rehabilitation}

Previously in this text, we have elaborated the use of children in armed conflicts and are still an ongoing problem. However, the solution is in not only the liberating and demobilizing of these children. The problem is significantly more complex, and its resolving depends on the preparedness of the community to provide them a return in their natural surroundings. The wealth and power of the culture and the tradition of the nations, who, faced such a terrible experience is a factor, very important factor, for success of this

\footnotetext{
${ }^{47}$ Narratives off former boy soldiers are suffused with expressions of their feelings... Fear was the most pervasive of these feelings. Child soldiers expressed fear of being taken to the battlefield to fight, fear of being killed, and fear of their commanders. The relationship between boy soldiers and older commanders was founded in terror. "Any wrong move, however slight, could result in death, possible not only in combat but also in the camps where soldiers were kept under constant surveillance."- Sonja C. Grover- " Child Soldier Victims of Genocidal Forcible Transfer- Exonerating Child Soldiers Charged With Grave Conflict- related International Crimes- Springer 20012, p. 91

${ }^{48}$ Evidence from several conflicts suggested that stigma against girls and women is so great that many who are eligible to go through DDR still choose not to go through formal or even informal (e.g. NGO arranged) reintegration programmes, hoping to avoid further marginalization. Yet, young women and girls who return from armed groups with children face stigmatization and marginalization from communities, whether they go through reintegration programmes or return independently.... Young mothers are often viewed by the community as having violated community norms by having children outside the recognized societal marriage norms... They are frequently labeled ass sexually promiscuous and can be regarded as "spiritually polluted"... In addition, these young mothers have often developed attitudes or habits during their time in the armed groups that are considered culturally inappropriate.- Same, p.225

49 "Children-soldiers-both, victims and offenders"/Politika/DW.COM/12.02.2013
} 


\section{Security}

complicated process. It is very important, to help this community in its military reconstruction.

Under UNICEF's patronage, the International Rescue Committee (IRC) and other humanitarian organizations, as well, a lot of programs, have been realized, in order to help in demobilizing and disarmament of underage juvenile soldiers, and sending them back to their families. The disarmament, demobilization and reintegration process, (the DDR process) is implemented in Bosnia and Herzegovina, Sierra Leone and other countries!

The Help and Reintegration program for children - soldiers, is very complex. It covers the period of their leaving of the unit, then, taking the children to transit-centers and bringing them back to their homes, eventually. Many different activities have been organized in the transit centers, where children psychologically recover. They again learn the behavior typical for normal children. There, they also study. They study basic literacy and mathematical operations. It is also very important, children to be taught on forgotten child games.

Later, after they go back to their families, the humanitarian organizations help the children to rebuild their ruined houses, to cultivate the forgotten fields, to restore the herd of cattle, or even to learn some craft.

(Carolyn Anyango, twenty-five, left the LRA near Kitgum, during a cease-fire, and was released along with four others. She relished her return to a normal life, living again with parents and going to school. She enjoyed math and science and hopped to become a scientist. However, the memories haunted her. "Sometimes (I) can still recall" life in the bush, she said with a shudder.

Was she also angry about what happened?

"I was," she said. "I feel anger because my future was wasted."

Was it possible to forgive and forget?

"It is not easy," she said.

Was she forced to commit atrocities?

No, she says, but she witnessed the murder of one young boy. "He was cut and beaten to death." $)^{50}$

\footnotetext{
${ }^{50}$ Peter Eichstaedt, "First Kill Your Family- Child Soldiers of Uganda and the Lord's Resistance Army- Lawrence Hill Books- 2009, p. 67
} 


\section{Securiagues}

Of course, the marks in their souls are big and their return to a normal life is a long and a complex process. The burden they carry will remain inside their memories and souls and it will last for the rest of their lifetime.

\section{Conclusion}

From the above mentioned in this text, the following can be concluded:

1. We will never find out the exact number of children killed, injured, raped or children who took part in armed conflicts as children - soldiers, in the world.

2. All adopted Conventions, Declarations, Protocols and Laws by the International Organizations, International Criminal Courts and Covernments of the countries, have no impact and influence to reduce or completely stop the abuse of children in armed conflicts. Many examples of children abused in conflicts, around the World, show that! Therefore, the only way to reduce or stop the abuse of the children is to reduce armed conflicts or stop the armed conflicts from ever happening!

3. The thing the International Organizations, Non - government Organizations and Government of the countries around the World (not all of them) can do, is to help with the Rehabilitation of the children - soldiers, in order to restore in full capacity their normal life's as much as possible.

In addition, at the end, we will speak a little bit more about the term, COLLATERAL VICTIM/DAMAGE! As stated in the introduction, this term for the first time was used by the US army in the Vietnam War. But there is a saying in the Macedonian language, old several hundreds of years, with a same or similar meaning as the term, Collateral Victim/Damage, and it goes like this: „Покрај сувото, гори и суровото "(Pokraj suvoto, gori i surovoto) or literary translated in English: "With the dry material , burns ${ }^{51}$ the raw ${ }^{52}$ material , as well ". That means that, in a fire, can and will burn the, thing" that shouldn't be burning. The, thing" that shouldn 't be burning, is, the Collateral Victim/Damage. So, in an armed conflict, the, thing" (the raw material) that shouldn 't be burning, are the Children!

\footnotetext{
${ }^{51}$ The word "burn" ("гори") here, has meaning of suffering.

52 The word "raw" ("суровото") here, has meaning wet material.
} 


\section{Security}

\section{Bibliography}

1. Boko Haram reportedly kidnapped more than 400 woman and children in Damask"Reuters, 03/24/2015

2. Eigen, Louis D. "Child soldiers are unfortunately nothing new", Scriptamus. wordpress.com, Retrieved on 26 April 2015.

3. Children-soldiers-both, victims and offenders"/Politika/DW.COM/12.02.2013

4. Children like a cannon fodder on the Fronts", "Dnevnik", 22.03.2013

5. Children warriors from Bosnia, abounded by foreign countries, Balkan Insight, 21 may 2014

6. David M. Rosen, "Armies of the young: Child Soldiers in War and Terrorism"Rutgers University Press: New Brunswick, New Jersey, and London 1989

7. "Hitler Youth", the History Place, Retrieved on 15 April 2015.

8. "Interesting Facts About World War II", Armed Forces History Museum, Retrieved on 10 April 2015.

9. Law on Child Protection- official Journal of Republic of Macedonia, num. 23, 14.02.2013

10. IVM Staff. "The Real Dad's Army", Imperial War Museum, Retrieved on 22 April 2015.

11. Michael Leggiere, the fall of Napoleon: The Allied Invasion of France 1813-1814, pg. 99-100.

12. Myriam Denov, "Child Soldiers- Sierra Leone's Revolutionary United FrontCambridge University Press- 2010

13. Momćilo Gavrić - najmlađi vojnik Prvog svetskog rata."Vecernje novosti" 13 avgust 2013

14. Peter Eichstaedt, "First Kill Your Family- Child Soldiers of Uganda and the Lord's Resistance Army"- Lawrence Hill Books- 2009

15. Simkin, John. "The Red Army", Spartacus Educational, Retrieved on 23 April 2015.

16. Sonja C. Grover, "Child Soldier Victims of Genocidal Forcible Transfer- Exonerating Child Soldiers Charged With Grave Conflict- related International Crimes"- Springer 2012

17. Soldiers smaller than a rifle: abducted childhood", Vreme num. 563, 18.10.2001

18. S: Rome Statute of the International Criminal Court Article 8 - War crimes. 


\section{Secururity}

19. Momcilo Gavric-the youngest soldier in the World War-One"- Vecernje novelty, 13 avgust 2013

20. UNICEF: "In 2014 over 15 million of children were victims of violence in the World", "Utrinski vesnik", 08.12.2014

21. "UNICEF: Optional Protocol to the Convention on the Rights of the Child", Journal of International Humanitarian Legal Studies 5 (1-2): 213-257. Retrieved 30 January 2015.

22. United Nations Security Council Resolution 1261. S/RES/1261(1999).

23. United Nations Security Council Resolution 1612, S/RES/1612(2005).

24. United Nations Security Council Verbatim Report 5936. S/pv/5936. 